\title{
PENDEKATAN EMPIRIK DALAM ANTROPOLOGI HUKUM
}

\author{
Nama : Hafizul Ihsan \\ Email: hafizulihsan98@gmail.com \\ No BP: 2010003600116 \\ Universitas Eka Sakti
}

\section{A. PENDAHULUAN}

Antropologi mempelajari kebudaya-an manusia sebagai suatu yang utuh di mana bagian-bagiannya saling berkait-an. Karena itu maka hukum yang di-amati bekerja di semua kebudayaan manusia, tidak dipelajari secara tersen-diri, tetapi dilihat brkaitan dengan, segisegi yang lain dari masyarakat dan kebudayaan. Dalam usaha menelaah hukum, misalnya maka latar belakang budayanya merupakan hal yang penting dipelajari. Antropologi mempelajari gejala-gejala masyarakat, secara lintas budaya, artinya konteks di mana gejala itu terdapat tidak hanya dibatasi pada suatu kebudayaan tertentu. Seorang ahli hukum yang biasa dengan hukum yang terdapat dalam masyarakat modern, tanpa menyadarinya sering menganggap hukum, identik dengan hukum yang sesuai dengan sistem masyarakat yang sudah modern. Maka dia tidak peka terhadap hukum yang berlaku berdasarkan kekuatan hukum rakyat. Lain halnya dengan pendekatan anthropologi.

Antropologi mengamati bahwa dalam masyarakat mana pun selalu ada usaha untuk mewujudkan ketertiban sosial keteraturan sosial. Ini tercapai akibat dari suatu mekanisme yang disebut pengendalian sosial. Mekimisme itu dipandangnya sebagai suatu kontinuum, suatu yang berkesinambungan, karena berbagai. norma pengatur kelakuan, oleh para warga masyarakat tidak dihayati secara tegas terpisah.

Atropologi menelaah, hukum itu dengan bertolak dari kenyataan dengan pendekatan empiris. Dalam pengamatan-pengamatan empiris kelihatan bahwa hukum yang dirumuskan secara universal, artinya berlaku umum untuk suatu wilayah tertentu, dalam penerapannya diwarnai oleh ciri-ciri lokal; Hal lain yang juga sangat disadari ada-lah bahwa hukum formal 
adalah suatu cara pengaturan masyarakat yang diharapkan akan memungkinkan terwujudnya ketertihan. Dalam usaha mencapai kedamaian bila ada konflik-konflik, dalam masyarakat sendiri berkembang norma-norma ciptaannya sendiri, yang disepakati dan norma-norma informal demikian ini pun menjadi obyek telaah antropologi.

Berdasarkan pendekatan demikian terhadap hukum, maka dari segi kepentingan ilmu antropologi tidak lagi cukup diperoleh pemahaman mengenai bekerjanya hukum di berbagai masyarakat, diberbagai golongan dalam suatu masyarakat, dengan menekuni cabang-cabang ilmu yang ada yang menyoroti hukum itu. Suatu spesialisasi kemudian berkembang yaitu oleh sebagian dinamakan antropologi hukum oleh yang lain etnologi hukum. Dengan titik tolak terse but diatas maka dalam cabang ilmu itu, telah berkembang tradisi ilmiah untuk menelaah berbagai aspek hidup yang berkaitan dengan hukum di mana diterapkan metode-metode penelitian yang serasi dan berdasarkan penelitian-penelitian yang diadakan serta pendekatanpendekatan teoretis tertentu, maka., berbagai kerangka-kerangka pemikiran teori telah juga mengendap dalam cabang ilmu ini.

Perumusan masalah dan tujuan penelitian sedikit banyak telah menampakkan arah dan pendekatan yang akan diterapkan dalam penelitian itu. Perumusan masalah dan tujuan penelitian akan memberikan sinyal kearah manasuatu penelitian akan digarap dan pendekatan apa yang akan diterapkan, bila permasalahan dan tujuan penelitian terfokus pada unsur hukum idial (SoerjonoSoekanto et.al) atau konsep yang pertama kedua (Soetandyo Wignjosoebroto), maka pendekatan kajiannya terarah pada penelitian hukum normatif, namun apabila permasalahandan tujuan penelitian terfokus padaunsur hukum idiel atau konsep ketiga, empat atau ke lima, makapenelitian hukum itu akan menerapkan pendekatan empiris/sosiologis. 


\section{B. PEMBAHASAN}

Pengaruh ilmu sosial terhadap disiplin hukum adalah kalimat kunci yang sesuai sebagai pembuka pembicaraan mengenai jenispenelitian yangsatu ini, yaitu penelitian hukum empiris(empirical legal research). Kata"empiris" bukan berarti harus menggunakan alat pengumpul data dan teori-teori yang biasa dipergunakan di dalam metode penelitian ilmu-ilmu sosial,namun di dalam konteks ini lebih dimaksudkan kepada pengertian bahwa"kebenarannya dapat dibuktikan pada alam kenyataan atau dapat dirasakanoleh panca indera" atau bukan suatu fiksi bahkan metafisika atau gaib, yangsejatinya berupa proses berfikir yang biasanya hanya dongeng maupunpengalaman-pengalaman spiritual yang diberikan Tuhan tidak kepada setiapmanusia dan tidak harus melalui proses penalaran ilmiah suatu hal tertentudapat diterima kebenarannya, meskipun oleh para ilmuwan kadang dikatakantidak ilmiah atauan illogical phenomena. Penerimaan terhadap suatu yangbersifat ilmiah biasanya dipredikatkan dengan ungkapan“"masuk akal”,sedangkan penerimaan terhadap suatu yang bersifat metafisika dan spiritualbiasanya disebut sebagai kepercayaan.

Oleh sebab itu,penelitian hukum empiris dimaksudkan untukmengajak para penelitinya tidak hanya memikirkan masalah-masalah hukumyang bersifat normatif (law as written in book), bersifat teknis di dalammengoperasionalisasikan peraturan hukum seperti mesin yang memproduksidan menghasilkan hasil tertentu dari sebuah proses mekanis, dan tentunyahanya dan harus bersifat preskriptif saja, meskipun hal ini adalah wajar,mengingat sejatinya sifat norma hukum yang "ought to be" itu. Selanjutnyacara pandang sebagaimana disebutkan tadi bergeser menuju perubahan kearah penyadaran bahwa hukum, faktanya dari perspektif ilmu sosial tenyatalebih dari sekadar norma-norma hukum dan teknik pengoperasiannya saja,melainkan juga sebuah gejala sosial dan berkaitan dengan perilaku manusiaditengahtengah kehidupan bermasyarakat yang unik dan memikat untukditeliti tidak dari sifatnya yang preskriptif, melainkan bersifat deskriptif.Di sisi lain, mengingat para penstudi hukum sejatinya 
tidak terlatihmelakukan penelitian sebagaimana dimaksud, dan faktanya memang tidakdipersiapkan untuk itu, maka peranan para ilmuan sosial berikut metode-metode penelitian bahkan teori-teorinya dibutuhkan oleh sebagian penstudihukum yang ingin melakukan penelitian di bidang hukum denganmenggunakan pendekatan ilmu sosial (sociolegal research21) maupundisebut dengan penelitian hukum interdisipliner, karena kadangkadangbersentuhan dengan ilmu ekonomi, antropoligi, bahkan ilmu politik dan lainlain.Penelitian hukum normatif/doktrinal yang di dalam literaturhukumasing biasa disebut denganlegal researchdan tanpa tambahan makna lain,menurut sebagian penstudi hukum dikatakan sebagai penelitian hukum yangmurni (the pure legal research).22Mengapa demikianHal ini disebabkanoleh kenyataan bahwa disamping penelitian hukum yang murni sebagaimanatelah diuraikan diatas masih terdapat jenis penelitian lain yangmendampinginya dan biasa dipelajari oleh para penstudi hukum dibawahjudul kuliah "Metode Penelitian Hukum" (dalam hal ini di Indonesiakhususnya), danmungkin kenyataan ini yang menjadikan penelitian hukumdikatakan sebagai penelitian yang khas.

Jenis penelitian yang dimaksud adalahpenelitian hukum empiris atausocio-legal(Socio legal research)yang merupakan model pendekatan laindalam meneliti hukumsebagai objek penelitiannya, dalam hal ini hukumtidak hanya dipandang sebagai disiplin yang preskriptif dan terapan belaka,23melainkan jugaempiricalatau kenyataan hukum.Basis perkembangansocio legal researchdiUnited Kingdom/UKternyata beradadifakultas-fakultas hukum (law school) dan ditekuni olehpara penstudi hukum, bukan di fakultas-fakultas ilmu sosial (social science),meskipunsocio legal studysangat erat kaitannya dengan kajian sosiologihukum (sociology of law).24Socio legal studymerupakan studi hukuminterdisipliner maupun salah satu pendekatan dari penelitian hukum (amethodological approach) yang bahkan terkesan bertolak belakang sekalidari kajian hukum yang sifatnya doktrinal.Socio-legaltidak disamakandenganlegal sociologydinegara-negaraEropa Barat, bahkanlaw andsociology 
scholarshipdi USA, dimana peranan ilmu sosiologi lebihdominan dalam kajiannya."Socio". Dan di dalamsocio-legal studiestidakmengacu kepada ilmu sosiologi maupun ilmu-ilmu sosial, melainkan "aninterface with a context within which law exist"25oleh sebab itu, mengapa disaat para penelitisocio-legalmenggunakan teori-teori sosial tertentu sebagaialat bantu analisis tidak diarahkan untuk menjadi kajian ilmu sosiologi danilmu sosial lainnya, melainkandiarahkan untuk kajian ilmu hukum. Namunilmu sosiologi dan ilmu-ilmu sosial lainnya, bagisocio-legal studiessangatdiperlukan peranannya yaitu guna meminta/memperoleh data-data saja, halini sangat beralasan mengingat bahwa ilmu sosiologi misalnya, memilikikarakteristik yang deskriptif dan kategoris.

Berbeda dengan penelitian hukum normatif yang lebih dulu ada ditengah-tengah keluarga besar disiplin hukum,socio-legal researchbiasanyadikembangkan dalam suatu lembaga-lembaga independen, seperti diIndonesia misalnya: ELSAM dan HUMMA. Sedangkan di Negara lainsepertiInggris misalnya lembaga tersebut juga ada yang independen maupunberada dibawah naunganlaw schoolataufaculty of law, seperti:UniversityCollege London (UCL)School of Law UKdenganThe Centre for EmpiricalLegal Studies-nya. Dimana maksud dan tujuannya lembaga tersebutadalah:

Metode Penelitian Hukum Normatif dan Empiris Karakteristik Khas dari...Depri Liber Sonata30Berbeda dengan penelitian hukum normatif yang lebih dulu ada ditengah-tengah keluarga besar disiplin hukum,socio-legal researchbiasanyadikembangkan dalam suatu lembaga-lembaga independen, seperti diIndonesia misalnya: ELSAM dan HUMMA. Sedangkan di Negara lainsepertiInggris misalnya lembaga tersebut juga ada yang independen maupunberada dibawah naunganlaw schoolataufaculty of law, seperti:UniversityCollege London (UCL)School of Law UKdenganThe Centre for EmpiricalLegal Studies-nya. Dimana maksud dan tujuannya lembaga tersebutadalah:27“...to bring together experts across a range of social sciencedisciplines to engagein interdisciplinary research with a bearingon law. The 
Centre's ambitions are to be a world leader ofmethodological innovation in empirical legal studies, to buildresearch capacity in the United Kingdom and to promote theevidence led evolution of justice systems around the world.

Sedangkan bidang-bidang penelitiannya adalah:

"The emphasis of the work of the centre is on interdisciplinaryempirical research investigating the operation and effects of lawwithin the context of the social, economic andpoliticalenvironment. The work of the centre is concerned with the role andfunction of law, the enforcement of law, compliance with law,resistance to law, the use and experience of law, the impact of lawand the character of law itself'.

Ilmu hukum (jurisprudence) dan segala sub kajian yangmendampinginya di dalam keluarga besar kajian tentang hukum, terlepasdari kontroversinyasebagai sebagai suatu disiplin ilmu yang mandiri dankhas (sui generis), bagian dari ilmu humaniora maupun ilmu sosial,sebagaimana ilmu pengetahuan alam (eksakta) dan ilmu-ilmu sosial yangtelah memiliki tempat yang tak terbantahkan di ranting-ranting pohon ilmu.Ilmu hukum harus diakui memiliki metode penelitian yang khas sekaligusunik, baik dilihat dari kepentingan/kegunaan dilakukannya suatu penelitian di bidang hukum, baik teoritis maupun praktis, atau dari cara melihat ilmuhukum sebagai disiplin yang bersifat preskriptif dan terapan, maupun darisudut pandang prilaku manusia yang berkaitan dengan eksistensi hukum.

Lebih dari itu, hal yang terpentingadalah ketepatan saat menentukan pilihan terhadap jenis dan metode manayang terbaik atau paling sesuai bagi penelitian yang akandilakukannya, tentunya hal tersebut mengacu kepada kegunaan/tujuan danhasil akhir yaitu terjawabnya permasalahan yangmelatarbelakangi/menginspirasikan dilakukannya suatu penelitian hukumtertentu, kemudian yang tidak kalah penting adalah menjadi lebihberkembangnya kajian keilmuan hukum danterselesaikannyamasalah-masalah hukum baik sifatnya konkret (perkara hukum/legal disputes)maupun permasalahan pembangunan hukum dimasa mendatang. 


\section{PENUTUP}

Sebagai akhir sajian ini ingin diketengahkan pokok-pokok pikiran yang terkandungdi dalamseluruh sajian ini. Adapun pokok-pokok pikiran yang terkandung dalam sajianini adalah Ilmu Hukum sebagai suatu cabangilmupengetahuan terikat pada paradigma yang terjadi di dalamilmu pengetahuan pada umumnya, Paradigmailmu hukum menunjukkan kekhususannya sendiri, dalarn perkembangannya menunjukkan suatu perkembangan paradigmaticyang tidak terputus-putus melainkan bersifat berkelanjutan. Paradigmailmu hukum adalah hasil konstelasi kerangka keyakinan dan komitmen para ahli hukum terhadap ilmu hukum, berisi kajian-kajian rasional yang deduktif dan empiris yang induktif, bersifat meta-teoritik bertujuan untuk memanusiakan manusia yang mengedepankan etika moral dan estetika yang bersumber pada Sang Khalik. Kajian pendekatan dalam penelitian hukum sepenuhnya tergantung pada perrnasalahan dan tujuan penelitian hukum bersangkutan,bila permasalahan dan tujuan penelitian masuk unsur hukum idial atau konsep hukum ius constituendumdan ius constitutum, maka kajian pendekatannya bersifat yundis normative-logika deduktif, bila masuk unsurataukonsep hukum pola perilaku dan pemaknaan sosial, maka kajian pendekatannya bersifat empiris/sosiologis-logika induktif. Secara singkat dapat dinyatakan satu rumus atau formula Metode adalah fungsi dari Permasalahan dan Unsur Hukum; Metode adalah fungsi dari permasalahan dan konsep hukum. Pendekatankajian hukum normatif dan empiris/sosiologis masing-masing memiliki karakteristik sendiri-sendiri bila dilihat dari unsurunsur yang lazimnya terdapat dalam pembicaraan tentang metode penelitian. (metode pendekatan, kerangka pemikiran-konseptual/teoritik, data dan somber data, metode analisis data, pembuktian, langkah penelitian dan tujuan yang dapat dicapai secara maksimal dari penelitian). 


\section{DAFTAR PUSTAKA}

Gokma Toni Parlindungan S, Asas Nebis In Idem Dalam Putusan Hakim Dalam Perkara Poligami Di Pengadilan Negeri Pasaman Sebagai Ceriminan Ius Constitutum, Volume 2, Nomor 1, 2020.

Gokma Toni Parlindungan S, Pengisian Jabatan Perangkat Nagari Pemekaran Di Pasaman Barat Dalam Rangka Pelaksanaan Otonomi Daerah, Ensiklopedia Of Journal, Vol 1 No 2 Edisi 2 Januari 2019,

Harniwati, Peralihan Hak Ulayat Menurut Undang-Undang Nomor 18 Tahun 2004, Volume 1, Nomor 3, 2019.

Jasmir, Pengembalian Status Hukum Tanah Ulayat Atas Hak Guna Usaha, Soumatera Law Review, Volume 1, Nomor 1, 2018.

Jumrawarsi Jumrawarsi, Neviyarni Suhaili, Peran Seorang Guru Dalam Menciptakan Lingkungan Belajar Yang Kondusif, Ensikopedia Education Review, Vol 2, No 3 (2020): Volume 2 No.3 Desember 2020

Mia Siratni, Proses Perkawinan Menurut Hukum Adatdi Kepulauan Mentawai Di Sebelum Dan Sesudah Berlakunya Undang-Undang Nomor 1 Tahun 1974 Tentang Perkawinan, Ensiklopedia Of Journal, Vol 1 No 2 Edisi 2 Januari 2019,

Remincel, Dimensi Hukum Pelanggaran Kecelakaan Lalu Dan Angkutan Jalan Lintas Di Indonesia, Ensiklopedia Social Review, Volume 1, Nomor 2, 2019.

R Amin, B Nurdin, Konflik Perwakafan Tanah Muhammadiyah di Nagari Singkarak Kabupaten Solok Indonesia 2015-2019, Soumatera Law Review, Volume 3, Nomor 1, 2020. 